\title{
Leveraging social capital of the church for development: A case study of a farming community in Wellington
}

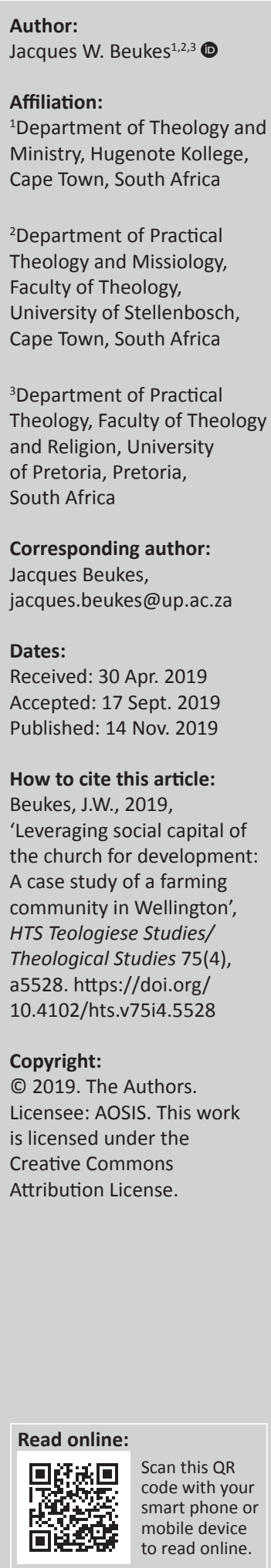

This article explores how a farming community in Wellington (Bovlei) moved from dependence towards an empowered community through non-profit organisations' (NPOs) transformative community development initiatives, undertaken together with the church's social capital. This example serves as the backdrop to explore critical viewpoints by various scholars who are critical about how the church engages in an unequal and unjust society. The critical questions that remain are the following; who is the church?, what is the church's role as a change agent? and how should churches leverage social capital for development? Although various definitions have been given in conceptualising the church and its role in society, through this article, the author engages with the social capital theory in understanding how the transformation came about in this community by describing the churches' involvement through a case study.

Keywords: Social capital; Church; Development; Community; Faith-based organisations.

\section{Introduction}

The 'tot' or 'dop' system, a system in which farmworkers are compensated with alcohol in place of wages after a long week of labour, is an unusual and seemingly tenacious feature of South African agriculture, especially in the Western Cape (Te Water Naude et al. 1998:1102). The origin of the 'dop' system traces back to the early colonial years in the Cape when indigenous pastoralists and coastal people were used to enter service on farms in return for payment with tobacco, bread and wine instead of wages (Te Water Naude et al. 1998:1102; cf. Williams 2016). Soon thereafter, the 'dop' system became a customary element of agricultural practice in the Cape over the next three centuries, and it became an important element of the social control exercised over the local people of the region. This was also the case in the Cape Winelands Area in the Western Cape. Consequently, because of the legacy of the 'dop' system, high levels of alcohol abuse have been reported amongst farmworkers in the Western Cape. Similarly, high levels of alcohol-related trauma in rural areas have been reported (Te Water Naude et al. 1998:1102). This legacy of the 'dop' system led to various socio-economic challenges, such as public health issues, poverty, domestic violence, crime, homelessness, substance abuse, sexual risk performance, family disruptions and unemployment, which was the cause for an unequal society, especially in various farming communities (cf. London 1999:1407; Setlalentoa et al. 2010:11-15).

In the Wellington Bovlei area, the Adama Foundation Trust, registered as a non-profit organisation (NPO), which consisted of a few farms under the management of the Bosman family, decided to move towards empowerment and transformational developmental model for farmworkers. Together with the assistance of Fairtrade, ${ }^{1}$ they have started a social development leg and also gave farmworkers shares in the farms and its profits. Consequently, personal development, management development, skills training and workshops were conducted over time. The critical question that one may ask is, 'if all of these were the initiatives of the Adama Foundation Trust (registered as an $\mathrm{NPO})$, then where the church is in these endeavours?'

Situated within the centre of all these farms is a congregation with the name Uniting Reformed Church in Southern Africa (URCSA) Wagenmakersvallei.

\footnotetext{
1.Fairtrade serves the interests and rights of farmers, workers and producers. Over the last eight years, Fair Trade Label of South Africa (FLSA) has played an important role in the implementation and promotion of the Fairtrade Standards and the Fairtrade Mark within the Southern African markets. Fairtrade is an alternative approach to conventional trade and is based on a partnership between producers and consumers. When farmers can sell on Fairtrade terms, it provides them with a better deal and improved terms of trade. This allows them the opportunity to improve their lives and plan for their future. Fairtrade offers consumers a powerful way to reduce poverty through their everyday shopping. When a product carries the FAIRTRADE Mark, it means the producers and traders have met Fairtrade Standards. The Fairtrade Standards are designed to address the imbalance of power in trading relationships, unstable markets and the injustices of conventional trade (cf. www.fairtrade.net, www.fairtrade.org.za).
}

Note: Faith-Based Organisations, sub-edited by Nadine Bouwers du Toit (Stellenbosch University), Vhumani Magezi (North-West University) and Elisabet le Roux (Stellenbosch University). 
Although the congregation cannot claim ownership of the social development initiatives, as it is the Adama Foundation Trust NPO that started the whole concept, it is the whole idea of shared resources through bridging social capital and social cohesion which I want to embark on in this article to illustrate the churche's involvement in the society of public life. The make-up of this farming community is that the same church members, church council members, church leaders and church ministries are all involved in these projects, but not as the local congregation per se. These members live on the farms, attend church on the farms, are farm shareholders and are all involved in their own development and community development initiatives. This brings me to the question of who the church is and how the church is involved in this community development project. Also, how should the church leverage its social capital for development and social transformation? Furthermore, how should we understand the social capital theories and shared resources within this specific community?

Various researches (cf. August 2010; Beukes \& Plaatjies van Huffel 2016; Bowers du Toit 2012, 2016; Magezi 2017; Swart 2006, 2008; Van der Westhuizen \& Swart 2015) indicate that the churches should be involved in public life as it has an essential role to play in community development.

Bowers du Toit (2016) concurs by saying:

Within theology and development discourse, a critique of the church's engagement with poverty as limited to notions of charity and/or pragmatic interaction with the state in South Africa has been critiqued by various scholars over the past 10 years. (p. 1)

However, although research encourages the church for a pragmatic interaction, the role of the church is still not well understood.

This is so despite the significant recognition in the last decade where the role of faith communities as potential frontrunners in community development initiatives was emphasised. Magezi (2017:1) affirms and believes that faithbased organisations (FBOs), particularly churches ${ }^{2}$, are a crucial role-player in community responses. However, the conceptualisation and understanding of church and FBOs also cause confusion.

With regard to the role of the church and other FBOs, Swart (2010:326) highlights that there is an increasing interest in the international debate amongst scholars about the relationship between social capital and development in the role of churches and other FBOs as agents of social capital formation. He further expresses that in the increasing amount of scholarly contributions on the theme of social capital, strong

2.Churches and congregations could also be described as FBOs. However, there is also a degree of complexity attached to the signifier of ' $\mathrm{FBO}$ ', as it is often broadly used a degree of complexity attached to the signifier of 'FBO, as it is often broadly used to refer to a wide range of faith-based actors that includes faith-based representative organisations, faith-based charitable or development organisations, faith-base sociopolitical organisations, faith-based missionary organisations and even faithbased illegal or terrorist organisations (cf. Beukes \& Van der Westhuizen 2018:1 Bowers du Toit 2017:2; Clarke 2006:840). In this case study, therefore, the specific church or congregation are also referred to as an FBO. empirically founded arguments are being presented about the strategic role that faith-based traditions and their associated organisations - such as churches - are playing in mobilising the kinds of social capital that lead to communal actions of collective social outreach and caring (Swart 2010:326). Therefore, in this article, I will explore the social capital theories and explain the case study within this setting; however, I will first briefly discuss on the conceptualisation of the terms such as 'church', 'FBOs', 'non-governmental organisations (NGOs)', 'NPOs' and 'community-based organisations (CBOs)'.

\section{Conceptualising church, faith-based organisations, non-governmental organisations, non-profit organisations and community- based organisations \\ Church}

The concept of church is multifaceted and refers to several theological concepts as it finds expression in different ways in society (Forster \& Oostenbrink 2015:5). Becaue of this complexity of the definition of the concept of church and also because it is not the primary purpose of this article, I will abstain from engaging in an all-inclusive wide-ranging exploration of the definitions and discourses on the concept of church.

Instead, for the sake of this article, I will draw on Smit's (2007) contribution to the conceptualisation of church. According to Smit (2007), at least six forms or manifestations of the church should be distinguished when conceptualising the identity and calling of the church:

1. the church as ecumenical church (whether global, national, regional or local)

2. the church as denomination(s)

3. the church as (mostly local) congregations

4. the church as worshipping communities

5. the church as individual believers (in the fullness of their personal, private and public lives)

6. the church as believers (individuals or groups) participating in initiatives and actions, together with others. (p. 265)

It is especially on Smit's (2007) fifth and sixth manifestations of the church that I want to draw my attention. Acknowledging the fifth and sixth manifestation of church would mean, with regards to this case study, that the church is (actively) involved in the public life of the Wellington (Bovlei) area through both the individual and the community of believers in the fullness of their personal, private and public lives. They are participating in initiatives and actions together with others for the common good, transformation and well-being of each other and the community. According to Korten (1990:117-118), the mode of engagement within the local community as described above is characterised as second generation involvement. The second generation 
involvement refers to the empowering of a community, often through projects and development initiatives (cf. Beukes \& Plaatjies van Huffel 2016).

According to Bowers du Toit (2017), institutions of faith, such as congregations and churches, could also be described as FBOs. However, although conceptualising FBOs has its own complexities, I will briefly explain FBOs in the next section.

\section{Faith-based organisations}

Swart and Van der Merwe (2010) are of the opinion that although research with regard to FBOs has been on the increase, its agenda has been modest in comparison with the research of secular NGOs or multilateral agencies (cf. Olsen 2008:393). Within the South African context, this is especially evident in the lack of comprehensive research on the current and potential role of FBOs in the country (cf. Bowers du Toit 2017; Swart \& Van der Merwe 2010:75). It is, nevertheless, clear that NGOs (of which FBOs form a part) play an important role in addressing a range of socioeconomic challenges within South Africa and are often working at the coalface of poverty and inequality, addressing the poorest and most vulnerable members of society (Patel 2012:610). Patel (2012:605, 616), in fact, makes the point that, during apartheid, it was NPOs that provided alternative social services and community development to the majority black populace. Patel (2012:615) also highlights the need for NPOs to keep the current government accountable by 'maintaining a critical eye'.

For many FBOs, religion is far more than an 'essential component of identity ... it is a source of well-being' (James 2011:3).

In this manner, many FBOs challenge the assumptions of traditional development theory, which view the spiritual and physical domains as separate (Myers 2011:7-10).

Magezi $(2007,2008)$ regards churches as subsystems of a community that people live in (Magezi 2017:9).

In a previous contribution,Magezi (2012) has drawn the confusion of the use of the concept of 'church' and its usage in sacred writings (Bible), whereby the daily use of the concept is interchangeable in three ways, namely:

[F]irstly as reference to a local assembly or congregation, denomination and universal church; secondly it outlines the typology of churches' work in development and or diakonia; and thirdly it refers to the congregational ecology where a local assembly arises to respond to community needs organically. (pp. 4-5)

This brings me to a brief exposition of the concepts of NGOs, NPOs and CBOs. The definition of these concepts is very broad and it is, just as in the case of the concept of church, beyond the scope of this article to enter into a comprehensive analysis of the definitions and discourse surrounding these three concepts.

\section{Non-governmental organisations}

According to Korten (1990), there are different types of NGOs that have little or nothing in common with each other. Thus, to speak about the roles of NGOs, it is necessary to specify what type of NGOs we are talking about. In his attempt to solve this problem, Korten (1990) has identified four main types of NGOs. They are Voluntary NGOs which pursue a social initiative driven by a commitment to shared values; Public Service Contractors (PSCs) which function as marketoriented NPOs for the purpose of serving the public; People's Organisations (POs) which represent their members' interests, have member accountable leadership and are highly self-reliant; and Governmental Non-Governmental Organisations (GONGOs) which are creations of government that serve as instruments of government policy (cf. Beukes \& Plaatjies van Huffel 2016; Ferreira \& Groenewald 2010:183).

Non-governmental organisations are different from NPOs in that they are more structured and institutional than NPOs, and they often have various programmes with projects that span a large geographical area. It is often the case that NGOs would make monetary contributions to NPOs who implement projects that are aligned to their programmes. The current interchangeable usage of NGOs and NPOs in South Africa, with the reasoning that all NPOs are by nature non-governmental, also causes further confusion (cf. Swart 2006, 2010).

\section{Non-profit organisations}

The Department of Social Development defines NPO as a:

[T]rust, company or other association of persons established for a public purpose and of which its income and property are not distributable to its members or office bearers accept as reasonable compensation for service rendered. (www.dsd.gov.za/npo)

Therefore, the organisation's management structure sets the objectives for the organisation based on the alleged needs of the community, with or without community consultation. NPOs in South Africa are registered as an NPO (according to Department of Social Development), Non-profit Company (NPC) (according to Companies and Intellectual Property Commission) or Trust (cf. https://conclusive.co.za/ comparing-npo-types).

\section{Community-based organisations}

Community-based organisations are small organisations initiated by the local people of the specific communities that they serve, or as Dill (2010:25) puts it, 'CBOs are typically formed by and for individuals residing in a geographically bounded and administratively defined area, usually a municipal sub ward'. Instead of outsiders coming into a community and playing the role of 'experts' in determining what the community should have to address their needs, in 
a $\mathrm{CBO}$, the inhabitants determine its own objectives and works together to achieve those objectives with or without outside help. Therefore, CBOs are also regarded as grassroots level organisations and can be formally or informally started by those who belong to the community they function in (Ndlovu 2004:8). If the CBO is faith-based, it may also be called an FBO.

\section{Social capital theories}

With the aforementioned discussion as a backdrop, the concept of social capital is explained in this section.

The concept of social capital has mainly been influenced by the work of Pierre Bourdieu (1986), James Coleman (1988, $1990)$ and Robert Putnam $(1993,2000)$. Social capital is about the effects and consequences of human sociability and connectedness and their relations with the individual and social structure. The concept of social capital is not new and is mainly related to the fields of sociology, political science and research on social capital in the social sciences, yet conceptualising social capital remains a challenging undertaking. Mainly because 'social capital exists between actors, it is not attributable to an actor like human and economic capital are' (Coleman 1988:S98; S113). Consequently, various definitions and theories have been proposed to grasp the understanding of the concept of social capital (cf. Sato 2013:1).

Cloete (2014:2) in her exploration of the term 'social capital' also used the definition of Bourdieu and Coleman who defined social capital as '... a range of resources available to individuals thanks to their participation in social networks' (cf. Herreros 2004:6). Similarly, Bartkus and Davis (2009:2) define social capital '.. as a representation of the resources that arise from relationships and which could assist individuals and the collective to reach their goals in working towards the common good' (cf. Cloete 2014:2). From this definition, Bartkus and Davis (2009:4) continue and highlight two approaches for social capital, namely, the functional approach and the descriptive approach, which are briefly explained.

The first approach, namely the functional approach, is from the work of Putnam (1993:163) who describes social capital as the 'features of social organizations, such as trust, norms and networks that can improve the efficiency of society by facilitating coordinating actions' (cf. Sato 2013:1). It is noticeably that Putnam (1993:163) adds the concept of trust and norms to the social network core. Inaba $(2007,2011)$ adds externality of mind to the three elements of Putnam's definition. This addition of 'externality of mind' by Inaba $(2007,2011)$ illuminates the influence of positive relationships or functioning amongst people as it will mean that the good will of a person will have positive effects on other people.

Contrary to Putnam and Inaba, Lin (2001:29) embraces a more individualistic interpretation of social capital, adding resources to the social network core. He defines social capital as 'resources embedded in a social structure that is accessed and/or mobilized in purposive actions' (Lin 2001:29). From here stems the second approach, namely, the descriptive approach. This approach derives from the work of Nahapiet and Ghoshal (1998:243), who describe social capital as 'the sum of actual and potential resources embedded within, available through and derived from the network of relationships possessed by individuals or social unit' ( cf. Cloete 2014:2). According to Bartkus and Davis (2009:4), scholars have a tendency to accentuate the resources or effects of social capital in defining social capital (cf. Cloete 2014:2).

Social capital can also be defined at the individual, meso and societal level. The works of Bourdieu (1986), Burt (1992) and Lin (2001) come to mind when defining social capital at the individual level, while the works of Coleman $(1988,1990)$ and Putnam (1993) can be used to define social capital at the meso (community) and societal levels, respectively. Bourdieu (1986) defines social capital as:

[T] he aggregate of the actual or potential resources which are linked to possession of a durable network of more or less institutionalized relationships of mutual acquaintance and recognition ... which provides each of its members with the backing of the collectivity-owned capital, a 'credential' which entitles them to credit, in the various senses of the word. (pp. 248-249)

Bourdieu's (1986:248-249) emphasis is on individuals as receivers and holders of social capital. Contrary to Bourdieu, Coleman (1988:98, 1990), in his definition, focuses on the meso level as he defines social capital by its function.

Although many other approaches have been proposed with regard to the classification of different types of social capital, I briefly want to focus on the approach that categorises social capital into cognitive and structural forms (cf. Uphoff 1999). Here, in the first approach, a distinction can be made between the structural and the cognitive forms. The structural form of social capital includes roles, rules, precedents, procedures and social networks, while the cognitive form comprises norms, values, attitudes and beliefs. These two forms interact with each other. The structural form creates the cognitive form, which is a cycle that then reinforces or recreates the structural form. A second approach emphasises on the functions of social capital, that is, how social capital connects actors. Another famous categorisation distinguishes between bonding and bridging social capital (Gittell \& Vidal 1998; Putnam 2000). As the name suggests, bonding social capital bonds actors covered by it, whereas bridging social capital bridges actors with other actors outside. This contrast of social capital is illustrated by the differences in the conceptualisation of social capital between Coleman (1990) and Burt (1992). Woolcock $(1998,2001)$ added a third element, namely, 'linking social capital' to bonding and bridging. 'Linking social capital' links people to formal organisations, permitting them to have access to institutional resources. 
It allows citizens to access institutional resources that illuminate the church not only as a community but also as an individual accessing resources of the Adama Foundation Trust NPO and vice versa. Within the sharing of resources, social capital is also reciprocal; in other words, all parties in the network benefits.

From the literature review which conceptualises social capital, it is not an individual endeavour, but rather the totality of the efforts of people that participate in any form of the social network to create or build social capital that results in the public good or common good, even for those who did not participate. It is clear from the explanation earlier about the functional approach of social capital that trust, norms, social network (cf. Putnam 1993:163) and reciprocity (cf. Inaba 2007; 2011) seem to be prominent in social capital formation. Trust is essential in this process of 'externality of mind', which allows people to expect good from others (reciprocity) and to act on behalf of others to create a better future for all. Participation is influenced by information because the more relevant information people have about each other, the more eager they are to participate. Similarly, with regard to trust, the more information is shared the more trust or distrust is created, confirmed or destroyed. Therefore, according to Putnam (2000):

[The] public good feature of social capital could be viewed as a positive attribute, but at the same time it could lead to underinvestment in social capital as people do not receive all the benefits from it, but have to share it with others, even with those who did not participate or contribute. (p. 20)

To create trust and guarantee reciprocity, norms and values are needed to guide the process of participation in networks. It seems that people with values like honesty, trustworthiness, integrity and care for fellow humans are likely to create social capital, which could lead to the formation of a public good that brings me to the next section of church and social capital.

\section{Church and social capital}

According to Pieterse (2011:4), religious people are social capitalists based on their active involvement in volunteering work both inside and outside the church. On the agenda of various faith communities is the discourse of how to be actively involved in the socio-economic needs of the individual, communities and the society at large. Amongst religious people and faith communities, the outreach to the poor comes in different forms. In some cases, it involves an informal outreach of individuals or small groups of people, while in other cases, it is more systematised and organised programmes aimed at a whole community (Swart \& Van der Merwe 2010:84). It is here where I want to draw on the three concepts, which came from my earlier exposition of social capital, namely, bonding, bridging and linking (cf. Pieterse 2011:4). Bonding social capital tends to reinforce exclusive identities. Bridging social capital tends to bring various people together across diverse and social divisions. Linking social capital emphasises and implies reaching out to people outside the community (cf. Woolcock 1998, 2001). These three types of social capital make religious people social capitalists.

However, Cloete (2014:4) cautions that the flipside is also true with regard to church (religion) and social capital. She engages critically and states that (Cloete 2014):

[T] he focus on church (religion) and social capital could be associated with questions like whether social renewal is possible without moral renewal, or does religion matter in the public sphere? (p. 4)

Therefore, she believes that this emphasis on religion by no means views religion as the ultimate uniting factor in social cohesion. The flipside is that religion also has the power to divide. Even Putnam (2000:301) describes this 'flipside' as the dark side of social capital formation by religious involvement as 'secretarian social capital', which causes intolerance, especially in fundamentalist churches or groups. The saddening fact that religion and church divided people along racial and economic lines, specifically in the South African apartheid era, is another example of how religious social capital can hamper social cohesion ${ }^{3}$ (cf. Hewitt 2017; LefkoEverett et al. 2018:1-6; Pillay 2017:9-11).

However, as argued so far and based on previous publications (cf. Beukes \& Plaatjies van Huffel 2016), I still see the church as a vital role-player in social transformation, and therefore also in the formation of social capital. Congregations, such as in the case of URCSA Wagenmakersvallei in this case study, are worthy examples of how religion could be of value in social capital formation where people (individual and communal) gather and build networks in a specific community. The church is a public institution that is also being explicitly seen as a community (Coleman 2003:36). Even in a fourth industrial revolution era of an accelerated technological period, where face-to-face interaction and contact are declining, many people are still belonging to and attending faith communities in South Africa. Belonging to a congregation is not simply an act of finding a spiritual connection, but it also offers a social context where people meet and naturally form social networks that are beneficial to the social capital formation (Cnaan, Boddie \& Yancey 2003:21). The 'being together' of believers enhances the probability that they will internalise the norms of the group and share activities with other members (bonding). Congregations not only have opportunities for believers to network or work together with other congregations (linking) but also opportunities to reach out to people outside their religious groups (bridging social capital) (Cnaan et al. 2003:26). Consequently, I will deal with the case study methodology in the next section, followed by the case study

\footnotetext{
3.South Africa, a country deeply divided by hundreds of years of colonialism and apartheid, has similarly recognised the importance of social cohesion. Much of South African policy discourse is premised on a lack or deficit of social cohesion within the country. The National Development Plan (NDP) and Vision 2030, for example, states: 'despite progress since 1994, South African society remains divided. Many schools, suburbs and places of worship are integrated, but many more are not. South Africa remains one of the most unequal economies in the world. The privilege attached to race, class, space and gender has not been fully reversed' (Lefko-Everett et al. 2018:1-6).

Research participants in Lefko-Everett et al.'s (2018) study identified religion and churches (amongst others) as dividing factors amongst people.
} 
itself to integrate the above-mentioned theory to illuminate the role of the church in development initiatives.

\section{Methodology, setting and context}

In this article, I utilised one of the most commonly used methods in research - the case study methodology. This method values ways of doing practical theology although it is neither unique to practical theology nor was it created and developed by practical theologians (Schipani 2012:91). Magezi (2017), another practical theologian in South Africa, is also of the opinion that a case study is a useful methodology that permits thorough and comprehensive in-depth, multifaceted studies of challenging and complex issues which occur in real-life settings. It is qualitative and descriptive in nature, and focuses intensely on an individual or small group of participants, drawing assumptions, deductions and suppositions only about that specific participant or group and only in that specific context. In a case study methodology, the focus is placed on exploration and description and is neither positioned on the discovery of universal truth nor on the discovery for causality relationships (Crowe et al. 2011:2).

The case study methodology is ideal for the discipline of practical theology, as it is not only merely a good instrument for both exploration and theory building but also a valuable tool for demonstrating or illustrating a given practical theological theory. According to Schipani (2012:96), the case study methodology has potential epistemic value; in other words, it has the probability of generating knowledge.

However, there are also limitations involved in the usage of a case study methodology. An obvious limitation or shortcoming of the case study methodology is the difficulty of generalising from one case to another. Another disadvantage is the timeconsuming factor, as it takes a large amount of time required to experience significant learning through the case study methodology (cf. Schipani 2012:99). Furthermore, developing an argument or case can become a limitless or aimless assignment for the researcher as using this method often has no clear limits on data gathering or writing. Moreover, there is also a threat that the researcher's personal views and selective memory or even the biased and predisposed views of people or documents from which the study is made will introduce misrepresentations and distortions into the material (cf. Schipani 2012:99).

The case study methodology can still establish reliability, trustworthiness or generalisability of findings regardless of the aforementioned limitation and critique and the fact that a case study methodology focuses on a small number of cases. This is based on the number of advantages in using the case methodology in research, teaching and supervision of ministerial practice and practical theology. A first advantage is that case studies help to bridge the gap between reflection and theory, on the one hand, and experience and practice, on the other hand. A case study can illuminate and demonstrate theoretical hypotheses, and the latter can also be drawn from particular case descriptions and analysis (cf. Schipani 2012:99). Furthermore (Schipani 2012):

[I]n-depth practical theological reflection focused on cases can unveil theory already inherent in practice as well as practice actively shaping theory. Theory building itself can thus be readily viewed as a special form of practice. It is a practice that fosters the development of skills of analysis, discernment and decision-making in addition to increased self-knowledge and awareness for the sake of vocational identity and practical theological and ministerial competence. (p. 99)

Researchers view case study methodologies as an essential methodology that offers a comprehensive understanding of a phenomenon or case. According to Magezi (2017):

$[A]$ case study is employed because of its ability to provide detailed appeal and understanding to the various dynamics of church community interactions, as well as dynamics that may not be captured in the same way if other methodologies were used. (p. 4)

Furthermore, the research design used in this article is qualitative. According to Denzin and Lincoln (1994:2), qualitative research is multi-method in focus, as it comprises an interpretive, naturalistic approach to its subject matter, which, in this case, is practical theology. Researchers using this approach study things in their natural context and attempt to understand, or interpret, cases and phenomena in terms of the meanings people bring to them. Because qualitative methods include a variety of research methods, such as qualitative questionnaires, documents, diary accounts, participant observation, ethnography and so on, qualitative researchers are spoilt for choice as they can use a variety of methods to develop their arguments and deep understandings of how people perceive their social realities and, in consequence, how they act within the social world (Denzin \& Lincoln 1994:14). For this article, I made use of the integration of multiple qualitative methods (cf. Mason 2002:59-60) as data were collected through an extensive review of project documents, project statistics, policies, reports, meeting agenda and minutes, observations and unstructured interviews with the community development practitioners. Approval and consent were obtained from the Adama Foundation board of trustees via the community development practitioner to use the information and documentation provided.

Subsequently, I shift my attention in the next section to this specific case study, mentioned hitherto in this article. As a point of departure, in particular, my interest as the church's involvement in public life utilising the social capital theory is explained in this article. I am thus referring to a rural farming community of Wellington called Bovlei, and also well known as Wagenmakersvallei. This community and local congregation are located in the heartland of the Western Cape wine district, more specifically in the Boland. As a practical theologian, I am in this regard especially interested in reflecting on the role and partnership of the mentioned NPOs and the church (in its fifth and sixth manifestations of Smit's definition), in this specific context. 


\section{Case study: Wellington farming community, the church and the Adama Foundation Trust}

In 1796, the South African Missionary Society established a ministry in Wellington, Bovlei area (which is also known as Wagenmakersvallei ${ }^{4}$ ). In this area, the gospel was ministered to slaves and to Khoikhoi people who worked as labourers on farms. In 1820, they were succeeded by the Dutch Reformed Congregation of Paarl, and a church building was constructed in Wellington, Bovlei area. The church is still used by the people of Bovlei today. This congregation, URCSA Wagenmakersvallei - which will celebrate its 200 years of existence in 2020 - is situated in the centre of approximately 40 farms (church wards) and consists of 2200 ordained and baptismal members as currently documented on the congregation's books. The congregation is also the owner of four primary school buildings which are rented out to the Western Cape Education Department. The majority of the farmworkers live on these 40 farms and also belong to this congregation.

In the Wagenmakersvallei (Bovlei) area, the Adama Foundation Trust is registered as an NPO, which consisted of a few farms under the management of the Bosman family. The initiative of transformative community development came from the Bosman Adama group. The Bosman Adama group belongs to the Bosman family. The Bosmans and their farms are well known for supplying and exporting young vines ('stokkies'). Five years ago, the workers of the Bosman Adama farms were given shares of the business. In the centre, at Bovlei, is a Victorian complex. Immediately next to this building is one of the oldest mission churches in South Africa, the URCSA Wagenmakersvallei, and the Wagenmakersvallei primary school is situated on the other side. The Victorian complex itself consists of a community centre, early childhood development centre and a clinic. At this Community Centre is a day-care centre, a computer room, a karate club, a library, music school, skills training for youth, offices, kitchen and cooking facilities, a neighbourhood watch, women's club, sports club and along with it home for retired staff members. Other services, such as drug rehabilitation, debt counselling and school holiday activities, are amongst the projects that are currently running.

Farmworkers and their families on the Bosman Family Vineyards were empowered through the Adama Appollo Workers Trust, a groundbreaking joint venture through which a 26\% Black Economic Empowerment (BEE) transaction included a shareholding in the land, winery and nursery (i.e. all facets of the business). A total of 500 ha of land was part of the transaction, while beneficiaries also share in the profits of the vine nursery.

Social initiatives were established by the local people and supported by the Adama Foundation Trust NPOs that are Fairtrade certified. Programmes at the Bovlei Community Centre are mentioned in Table 1.

4.Wagenmakersvallei was also previously known as val du Charron.
Table 1: Adama Foundation Trust Social Initiatives and Programmes Development resources and programmes

\begin{tabular}{|c|c|}
\hline Medical clinic & $\begin{array}{l}\text { At the clinic, trained healthcare workers are daily on duty. The senior } \\
\text { nurse's duty is once a week at the clinic. This means that members of } \\
\text { the community do not always have to travel to town. }\end{array}$ \\
\hline Library & $\begin{array}{l}\text { In the library, books and magazines are available for all ages for } \\
\text { research, homework, assignments and leisure purposes. The facility } \\
\text { is also a safe place for young people to do their homework after } \\
\text { school. }\end{array}$ \\
\hline $\begin{array}{l}\text { Community } \\
\text { meeting hall }\end{array}$ & $\begin{array}{l}\text { The community meeting hall is used for weekly meetings, elderly } \\
\text { activities, men's club, women's club, choir training and other skills } \\
\text { training. The community meeting hall consists of a fully equipped } \\
\text { kitchen. }\end{array}$ \\
\hline $\begin{array}{l}\text { Computer } \\
\text { centre }\end{array}$ & $\begin{array}{l}\text { New computers with the necessary software and hardware and } \\
\text { printers are installed in the computer centre. Computer training } \\
\text { classes run every evening during the week while learners can use } \\
\text { the facility and computers for homework and do research for school } \\
\text { projects during afternoon. }\end{array}$ \\
\hline $\begin{array}{l}\text { Counselling } \\
\text { office }\end{array}$ & $\begin{array}{l}\text { The counselling office is open for parenting, marriage, trauma and } \\
\text { debt counselling. }\end{array}$ \\
\hline Transport & $\begin{array}{l}\text { The centre has Toyota Quantum busses for transporting purposes. } \\
\text { These busses are used so that pupils can attend school daily. The } \\
\text { busses are also used for other school outings, medical visits to } \\
\text { hospitals or general practitioners, social projects, sporting trips, } \\
\text { funerals and other extramural activities. }\end{array}$ \\
\hline $\begin{array}{l}\text { Bovlei } \\
\text { Preschool }\end{array}$ & $\begin{array}{l}\text { Within the Early Childhood Development Programme, } 96 \text { children } \\
\text { are registered with eight full-time trained caretakers. The } \\
\text { programmes are weekly from 08:00 to } 17: 30 \text {, and it also has a } \\
\text { feeding scheme in place. For the programme content, curriculum } \\
\text { consultation services are used and the training and toy library is } \\
\text { offered by the Pebbles Project. }\end{array}$ \\
\hline
\end{tabular}

Source: Bosman Wines, n.d., Bosman Fairtrade Overview, viewed n.d., from https:// bosmanwines.com/wp-content/uploads/Bosman_Fairtrade_Overview.pdf.

Except for the running programmes at the community resource centre, the Adama Foundation Trust also makes bursaries available for workers who want to complete courses and further their studies. Furthermore, the Adama Foundation Trust also subsidises school fees of secondary school pupils annually.

With regard to long-term and sustainable development initiatives, the Adama Foundation Trust provided new housing for farmworkers and their families. The total number of community housings on farms is currently 146 houses. Besides these housing on farms, the NPO also built 20 apartments and a complex with 35 potential houses in and around Wellington.

With regard to sports and recreation, the community resource centre started with a cricket club, rugby club and karate club. For these activities, uniforms, equipment and transport are provided. Transport is one of the shared resources, and church members are usually transported from farms to church to attend the worship services. On the culture side, they have established a men's and women's club which focus on skills and potential development of men and women in the community, motivational speakers, provide community services (e.g. soup kitchen outreach, gardening and lawn planting for elderly) and camps where the focus is on marriage, parenting, trauma, life skills, etc. The Bosman Adama Farm choir serves as both community and church choir. They consist of both the youth and adults. They perform regularly and have won various accolades and competitions such as the Suidooster festival. All these abovementioned programmes contributed tremendously towards their self-esteem, confidence and empowerment.

\section{Herman (2017) argues that:}

... [I]n the complex webs of practices, discourses and relations that constitute power it is perhaps easy to foster marginalised 
individuals' belief that they are powerless but it is important to focus on the power that they already have. (pp. 60-80)

Empowerment is understood as an action that is done to people. This flawed understanding derives from the idea that disempowered people are often lacking the capacity to access resources or gain capabilities. Nonetheless, oppressed people must build their understanding of their situation as active actors as they know their situation best. Therefore, to be transformative, empowerment should be rooted in the priorities and agendas of the marginalised themselves.

This is exactly what happens through leveraging social capital. Farmworkers become co-owners of the project and bridging their social capital enhances empowerment both individually and collectively.

Empowerment is meant to develop agency and capabilities to participate in, change and hold accountable those individuals and organisations that impact one's life (Herman 2014:1929).

Although the Uniting Reformed Church of Wagenmakersvallei was not the major driving force behind the community development project, this was not according to Smit's manifestation of church in his explanation of church as a denomination at least, neither the church as worshipping community nor the church as a congregation. However, the church as individual and community of believers were actively involved as co-owners of the project as well as members of the congregation. Within this fifth and sixth manifestations of church together with the Adama Foundation Trust, the social cohesion could be viewed as the positive outcome of social capital formation for a community that in turn could lead to more social capital formation. The corpus of literature exposed that social capital formation rests on norms and values that guide the process, and I also argued earlier that religious capital, through congregations especially, could give agency to these elements. In any community development project, the monetary component is crucial.

Therefore, the Adama Foundation Trust as a Fairtradecertified organisation plays an important role with its financial expertise and networking influences. However, from a social capital perspective, the people at grass-roots level is equally important, if not the most important. This is because, as Coleman $(1988,1990)$ points out, 'social capital exists between actors; it is not attributable to an actor like human and economic capital are'. So often the social capital of congregations is overlooked. Therefore, the farmworkers and congregational members as co-owners of the project with their indigenous knowledge, potential, buy-in and agency are key to the success of this project. In this way, the project is both bottom-up and top-down.

The top-down model is structured around the use of professional leadership provided by external resources that plan, implement and evaluate development programmes (Macdonald 1995):
Community development programs using the top-down model typically focus on providing professional leadership to the development process coupled with supportive concrete services. Through the process of residents following the external leadership and accessing the services offered by the program, changes within community residents' perceptions, behaviors and ultimately their standard of living are believed to occur. (Larrison 2002:68)

Consecutively, the bottom-up model is structured around comprehensive community participation, motivating local communities, expanding learning opportunities, improving local resource management, replicating human development, increasing communication and interchange, and localising financial access.

For practitioners using the bottom-up model as structured by social development theory, participation in community-wide discussions, improved opportunities to learn and the sense of empowerment that comes with knowledge are the necessary precursors to accomplishing the stated and implied goals of community development (Billups 1990; Blanchard 1988; David 1993; Larrison 2002:68; Midgley 1993; Rubin \& Babbie 1993).

Both models when used to structure community development programmes share a common set of stated and implied goals. These goals are:

1. to effect changes in community residents' perceptions about how to improve their standard of living

2. to create community-oriented behaviours that are based upon the changes in community residents' perceptions

3. to improve the standard of living amongst a majority of community residents (cf. Ewalt 1997; Larrison 2002:69).

\section{Conclusion}

So often development is viewed in combination with other terms such as 'growth', 'change', 'transformation', 'progress', 'reformation' or even 'revolution' (Anderson 1996:15-30). However, development should be viewed in relation to a specific facet of our existence to comprehend it. The facet could be social, physical, economic or political. Anderson (1996:15-30), Davids, Theron and Maphunye (2005:18), Kotze (1997:11-28), Rubin and Rubin (1986:12-25) and many other scholars view the basic ingredient of development to change not just any change, but a definite improvement - a change for the better. This article not only highlights this fact but also integrates it with the social capital theory in understanding the churches' involvement in this case study.

I have argued that although there are various definitions of social capital, the fundamental elements seem to be trust, norms, networks and reciprocity that exist amongst individuals and groups. Although the church was not the major driving force behind the community development project, I have argued that the church as individual and community of believers were actively involved based on Smit's definition of church. The congregation, together with the NPO and the social cohesion, can be seen as the positive 
conclusion of social capital formation. I have also argued that religious capital, specifically through congregations, could give agency to these elements.

As developments are rooted in and amongst people, it should have something mutual in common with the community or society in question, and hence there is the need to use the Adama Foundation Trust NPO and URCSA Wagenmakersvallei as case studies. Development must make sense to the people in this specific context and must be in line with their values and their capacity. It must be socially, culturally, economically, environmentally and technologically appropriate. Because development is for people, it must be achieved by people. It is about human development - the quality of human life as people themselves define it (Magezi 2017:8-9).

\section{Acknowledgements}

This article acknowledges and values the work done by the Adama Foundation Trust. The material in this article is partly based upon information available and shared by the community development practitioner.

\section{Competing interests}

The author was attached to the congregation as a part-time reverend. He declared that he has no competing interest, financial or personal relationship(s) which may have inappropriately influenced him in writing this article.

\section{Author's contributions}

J.W.B. is the sole author of this article.

\section{Ethical considerations}

This article followed all ethical standards for a research without direct contact with human or animal subjects.

\section{Funding information}

This research received no specific grant from any funding agency in the public, commercial or not-for-profit sectors.

\section{Data availability statement}

Data sharing is not applicable to this article as no new data were created or analysed in this study.

\section{Disclaimer}

The views and opinions expressed in this article are those of the author and do not necessarily reflect the official policy of any affiliated agency of the author.

\section{References}

Anderson, M.B., 1996, Development and social diversity, Oxfam, London. August, K.T., 2010, Equipping the saints: God's measure for development, Printman, Bellville.
Bartkus, V.O. \& Davis, J.H., 2009, Social capital: Reaching out, reaching in, Edward Elgar Publishing, Northampton, MA. https://doi.org/10.4337/9781848445963

Beukes, J.W. \& Plaatjies van Huffel, M.A., 2016, 'Towards a theology of development in the Uniting Reformed Church (URCSA): Embodying Article 4 of the Belhar Confession', Missionalia 44(2), 224-240. https://doi.org/10.7832/ 44-2-138

Beukes, J. \& Van der Westhuizen, M., 2018, 'Moving from faith-based concerns to demarginalising youths through the circle of courage', HTS Teologiese Studies/ Theological Studies 74(3), a5013. https://doi.org/10.4102/hts.v74i3.5013

Billups, J.O., 1990, 'Toward social development as an organizing concept for social work and related social professions and movements', Social Development Issues 12(3), 14-26.

Blanchard, D., 1988, 'Empirical strategies of bottom-up development', ICA International IERD Regional Development Symposia, s.l., n.d., 1988, pp. 318-338.

Bourdieu, P., 1986, 'The forms of capital', in J.E. Richardson (ed.), Handbook of theory of research for the sociology of education, pp. 241-258, Greenwood Press, New York, NY.

Bosman Wines, n.d., Bosman Fairtrade Overview, viewed n.d., from https:// bosmanwines.com/wp-content/uploads/Bosman_Fairtrade_Overview.pdf.

Bowers du Toit, N.F., 2012, 'Theology and the social welfare practice of the church Exploring the relationship in the Paarl context', in I. Swart, A. Gouws, P. Pettersson, J. Erasmus \& F. Bosman (eds.), Welfare, religion and gender in post-apartheid South Africa: Constructing a South-North dialogue, pp. 257-268, Sun Press, Stellenbosch, South Africa.

Bowers du Toit, N.F., 2016, 'The elephant in the room: The need to re-discover the intersection between poverty, powerlessness and power in "Theology and Development" praxis', HTS Teologiese Studies/Theological Studies 72(4), a3459. https://doi.org/10.4102/hts.v72i4.3459

Bowers du Toit, N.F., 2017, 'Meeting the challenge of poverty and inequality? "Hindrances and helps" with regard to congregational mobilisation in South Africa', HTS Teologiese Studies/Theological Studies 73(2), a3836. https://doi. org/10.4102/hts.v73i2.3836

Burt, R.S., 1992, Structural holes: The social structure of competition, Harvard University Press, Cambridge, MA.

Cloete, A., 2014, 'Social cohesion and social capital: Possible implications for the common good', Verbum et Ecclesia 35(3), Art. \#1331, 6 pages. https://doi. org/10.4102/ve.v35i3.1331

Cnaan, R.A., Boddie, S.C. \& Yancey, G.I., 2003, 'Bowling alone but serving together: The congregational norm of community involvement', in C. Smith (ed.), Religion as social capital: Producing the common good, pp. 19-32, Baylor University Press, Waco, TX.

Coleman, J.S., 1988, 'Social capital in the creation of human capital', American Journal of Sociology 94, 95-120. https://doi.org/10.1086/228943

Coleman, J.S., 1990, Foundations of social theory, The Belknap Press of Harvard University Press, Cambridge, MA.

Coleman, J.S., 2003, 'Religious social capital: Its nature, social location and limits', in C. Smith (ed.), Religion as social capital: Producing the common good, pp. 33-48, Baylor University Press, Waco, TX.

Crowe, S., Cresswell, K., Robertson, A., Huby, G., Avery, A., \& Sheikh, A., 2011, 'The case study approach', BMC medical reserach methodology 11(2011), \#100. https://doi.org/10.1186/1471-2288-11-100

David, G., 1993, 'Strategies for grassroots human development', Social Development Issues 12(2), 1-13.

Davids, I., Theron, F. \& Maphunye, K.J. (eds.), 2005, Participatory development in South Africa: A development management perspective, Van Schaik, Pretoria.

Denzin, N. \& Lincoln, Y., 1994, Handbook of qualitative research, Sage, Thousand Oaks, CA.

Dill, B., 2010, 'Community-based organizations (CBOs) and norms of participation in Tanzania: Working against the grain', African Studies Review 53(2), 23-48. https:// doi.org/10.1353/arw.2010.0019

Ewalt, P.L., 1997 'The revitalization of impoverished communities', Social Work 42(5), 413-414. https://doi.org/10.1093/sw/42.5.413

Ferreira, C. \& Groenewald, C., 2010, 'Churches as providers of HIV and AIDS care', in I. Swart, H. Rocher, S. Green \& J. Erasmus (eds.), Religion and social development in post-apartheid South Africa, pp. 175-201, African Sun Media, Stellenbosch.

Forster, D.A. \& Oostenbrink, J.W., 2015, 'Where is the church on Monday? Awakening the church to the theology and practice of ministry and mission in the marketplace', In die Skriflig 49(3), Art. \#1944, 8 pages. https://doi.org/10.4102/ ids.v49i3.1944

Gittell, R. \& Vidal, A., 1998, Community organizing: Building social capital as a development strategy, Sage, Thousand Oaks, CA.

Herman, A., 2014, 'Are we there yet? Exploring empowerment at the microscale in the South African wine industry', Environ Plan A 46(8), 1927-1945. https://doi. org/10.1068/a46293

Herman, A., 2017, Practising empowerment in post-apartheid South Africa: Wine, ethics and development, Routledge, Abington.

Herreros, F., 2004, The problem of forming social capital: Why trust?, Palgrave Macmillian, Houndsmill. https://doi.org/10.1057/9781403978806

Hewitt, R.R., 2017, 'The church as Christ's broken body responding to the emerging global challenges in a divided world', HTS Teologiese Studies/Theological Studies 73(3), a4648. https://doi.org/10.4102/hts.v73i3.4648 
Inaba, Y., 2007, Social capital: Solving issues in contemporary economy and society by 'ties of trust', Seisansei Shuppan, Tokyo, Japan.

Inaba, Y., 2011, Introduction to social capital: From isolation to ties, Chuo Koron Shinsha, Tokyo, Japan.

James, R., 2011, 'Handle With Care: Engaging with faith-based organisation in development', Development in Practice 21(1), 109-117. https://doi.org/10.1080/ 09614524.2011 .530231

Korten, D.C., 1990, Getting to the 21st century: Voluntary action and the globa agenda, Kumarian Press, West Hartford, CT.

Kotze, D.A. (ed.), 1997, Development, administration and management: A holisic approach, Van Schaik, Pretoria.

Larrison, C.R., 2002, A comparison of top-down and bottom-up community development interventions in rural Mexico: Practical and theoretical implication for community development programs, Edwin Mellen, Lewiston, NY.

Lefko-Everett, K., Burns, J., Nontshokweni, S. \& Njozela, L., 2018, 'Exploring South Africans' understanding of social cohesion', SALDRU Working Paper Number 218 , SALDRU, University of Cape Town, Cape Town.

Lin, N., 2001, Social capital: A theory of social structure and action, Cambridge University Press, Cambridge, MA.

London, L., 1999, 'The "dop" system, alcohol abuse and social control amongst farm workers in South Africa: A public health challenge', Social Science \& Medicine 48(10), 1407-1414. https://doi.org/10.1016/S0277-9536(98)00445-6

Macdonald, L., 1995, 'NGOs and the problematic discourse of participation: Cases from Costa Rica', in D.B. Moore \& G.J. Schmitz (eds.), Debating development discourse: Institutional and popular perspectives, pp. 201-229, St. Martin's Press, Inc., NewYork.

Magezi, V., 2007, HIV and AIDS, poverty and pastoral care \& counselling: A home based and congregational systems ministerial approach in Africa, Sun Media, Stellenbosch, South Africa.

Magezi, V., 2008, 'Possibilities and opportunities: Exploring the church's contribution to fostering national health and well-being in South Africa', Practical Theology in South Africa 23(3), 261-278.

Magezi, V., 2012, 'From periphery to the centre: Towards repositioning churches for meaningful contribution to public health care', HTS Teologiese Studies/Theological Studies 68(2), Art. \#1312, 8 pages. https://doi.org/10.4102/hts.v68i2.1312

Magezi, V., 2017, 'Making community development at grassroots reality: Churchdriven development approach in Zimbabwe's context of severe poverty', In die Skriflig 51(1), a2263. https://doi.org/10.4102/ids.v51i1.2263

Mason, J., 2002, Qualitative researching, 2nd edn., Sage, London, UK.

Midgley, J., 1993, 'Ideological roots of social development strategies', Socia Development Issues 12(1), 1-13.

Myers, B.L., 2011, Walking with the poor: Principles and practices of transformationa development, 3rd edn., Orbis, Maryknoll, NY.

Nahapiet, J. \& Ghosal, S., 1998, 'Social capital, intellectual capital and the organizational advantage', Academy of Management Review 23(2), 242-266. organizational advantage', Academy of Mant
https://doi.org/10.5465/amr.1998.533225

Ndlovu, N., 2004, The Cinderellas of development? Funding CBOs in South Africa, Interfund, Johannesburg.

Olsen, E., 2008, 'Common belief, contested meanings: development and faith based organisational culture', Tijdschrift voor Economische en Sosiale Geographie 99(4), 393-405.

Patel, L., 2012, 'Development social policy, social welfare services and the non-profit sector in South Africa', Social Policy and Administration 46(6), 603-610.

Pieterse, H.J.C., 2011, 'A church with character and its social capital for projects amongst the poor', HTS Teologiese Studies/Theological Studies 67(3), Art. \#1046, 8 pages. https://doi.org/10.4102/hts.v67i3.1046
Pillay, J., 2017, 'The church as a transformation and change agent', HTS Teologiese Studies/Theological Studies 73(3), 4352. https://doi.org/10.4102/hts.v73i3.4352

Putnam, R.D., 1993, Making democracy work: Civic traditions in modern Italy, Princeton University Press, Princeton, NJ.

Putnam, R.D., 2000, Bowling alone: the collapse and revival of American community, Simon \& Schuster, New York.

Rubin, A. \& Babbie, E., 1993, Research methods for social work, 2nd edn., Brooks/Cole Publishing Company, Pacific Grove, California.

Rubin, H.J. \& Rubin, I., 1986, Community organizing and development, Merril Publishing, London.

Sato, Y., 2013, 'Social capital', Sociopedia.isa., 1-10. https://doi.org/10.1177/205 684601374

Schipani, D.S., 2012, 'Case study method', in B.J. Miller-McLemore (ed.), The WileyBlackwell companion to practical theology, 1st edn., Blackwell Publishing Ltd., West Sussex.

Setlalentoa, B.M., Pisa, P.T., Thekisho, G.N., Ryke, E.H. \& Loots, D.T., 2010, 'The social aspects of alcohol misuse/abuse in South Africa', South African Journal of Clinical Nutrition 23(3), 11-15. https://doi.org/10.1080/16070658.2010. 11734296

Smit, D.J., 2007, 'Essays in Public Theology: Collected Essays', in E.M. Conradie (ed.) Study Guides in Religion and Theology, SUN Press, Stellenbosch.

Swart, I. \& Van Der Merwe, W., 2010, 'Towards conceptualising faith-based organisations in the context of social welfare and development in South Africa', in
I. Swart, S. Green, J. Erasmus \& H. Rocher (eds.), Religion and social development in post-apartheid South Africa, pp. 75-89, Sun Media, Stellenbosch, South Africa.

Swart, I., 2006, The churches and the development debate: Perspectives on a fourth generation approach, Sun Press, Stellenbosch, South Africa.

Swart, I., 2008, 'Meeting the challenge of poverty and exclusion: The emerging field of development research in South African practical theology', International Journal for Practical Theology 12(1), 104-149. https://doi.org/10.1515/ijpt.2008.6

Swart, l., 2010, 'Churches as a stock of social capital for promoting social development in Western Cape communities', in I. Swart, S. Green, J. Erasmus \& H. Rocher (eds.), Religion and social development in post-apartheid South Africa, pp. 325-351, Sun Media, Stellenbosch, South Africa.

Te Water Naude, J., London, L., Pitt, B. \& Mahomed, C., 1998, 'The "dop" system around Stellenbosch - Results of a farm survey', South African Medical Journal (SAMJ) 88(9), 1102-1105

Todd, N.R. \& Allen, N.E., 2011, 'Religious congregations as mediating structures for social justice: A multilevel examination', American Journal for Community Psychology 48(3-4), 222-237. https://doi.org/10.1007/s10464-010-9388-8

Uphoff, N., 1999, 'Understanding social capital: Learning from the analysis and experience of participation', in P. Dasgaputa \& I. Serageldin (eds.), Social capital: A multifaceted perspective, The World Bank, Washington, D.C.

Van der Westhuizen, M.A. \& Swart, I., 2015, 'The struggle against poverty, unemployment and social injustice in present-day South Africa: Exploring the involvement of the Dutch Reformed Church at congregational level', Stellenbosch Theology Journal 1(2), 731-759. https://doi.org/10.17570/stj.2015.v1n2.a35

Williams, G., 2016, 'Slaves, workers, and wine: The "dop system" in the history of the Cape wine industry, 1658-1894', Journal of Southern African Studies 42(5), 893-909. https://doi.org/10.1080/03057070.2016.1234120

Woolcock, M., 1998, 'Social capital and economic development: Toward a theoretical synthesis and policy framework', Theory and Society 27(2), 151-208. https://doi. org/10.1023/A:1006884930135

Woolcock, M., 2001, 'The place of social capital in understanding social and economic outcomes', ISUMA: Canadian Journal of Policy Research 2(1), 11-17.

Department of Social Development, Republic of South Africa, All about non-profit organisations, viewed 06 June 2019, from www.dsd.gov.za/npo. 